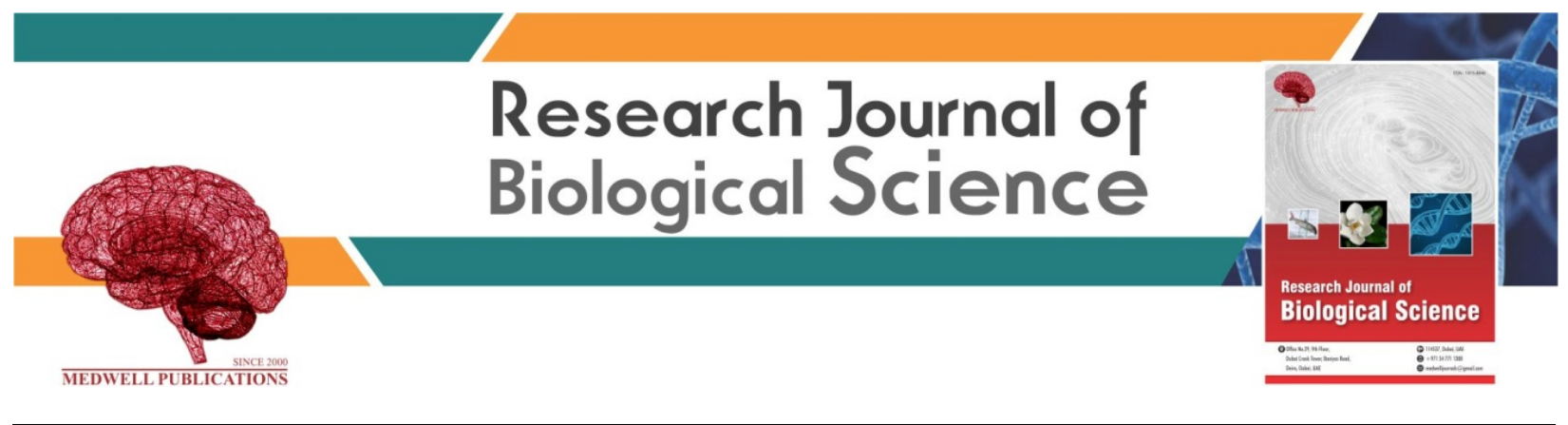

\title{
Fungal Pathogens of Postharvest Rot of Groundnut (Arachys hypogaea L.) in Hong Local Government Area of Adamawa State Nigeria
}

\author{
P. Asama and F.K. Channya \\ Department of Plant Science, Modibbo Adama University of Technology, Yola, Nigeria
}

Key words: Groundnut, postharvest rot fungi, Hong L.G.A., Adamawa State, Nigeria, practices

Corresponding Author:

F.K. Channya

Department of Plant Science, Modibbo Adama University of Technology, Yola, Nigeria

Page No.: 5-14

Volume: 15, Issue 1, 2020

ISSN: $1815-8846$

Research Journal of Biological Sciences

Copy Right: Medwell Publication
Abstract: Fungi such as Aspergillus niger (brasiliensis) Aspergillus flavus, Alterneriadia nthocola, Curvularia lunata, Curvulari apellesecens, Fusarium oxysporum, Fusarium equiseti, Microphomina phaseolina, Rhizopus stolonifer, Penicillium digitatumare associated with heavy losses of seeds, fruits, grains, vegetables and other plant products in transit and storage rendering them unfit for human consumption. The research sought to identify fungal pathogens of groundnut rot in storage in Hong Local Government Area of Adamawa State, Nigeria a major groundnut producing area. A survey was carried out using random sampling on incidence of groundnut rot in the seven districts of Hong Local Government Area in the month of July 2016. Isolation and identification, frequency of occurrence, virulence as well as effect of pathogens on germination of groundnut seeds and seedling growth were carried out. Incidence of rot occurred in all 7 districts with the highest in Hong, Hildi and Gaya, pathogens associated with the rot were identified as follows; Aspergillus niger (brasilensis) Aspergilus flavus, Penicillium chrysogenum, Rhizopus stolonifer, Paecilomyces lilacinus, Pseudallescheria boydii, Cylindrocarpon lichenicola and Scedosaporium prolificans. The frequent occurring fungi were Aspergillus niger (brasilensis) and Aspergillus flavus while the most virulent was Aspergillus flavus. There was significant reduction in seed germination and seedling growth at 99.99\% probability level for both the Valencia (Kampala) and Peruvian (Kwathrumthrum) from 33.33\% for uninoculated to $11.00 \%$ for inoculated. Proper storage practices to reduce groundnut rot as well as enhance seed viability are therefore, suggested.

\section{INTRODUCTION}

Agriculture remains significant in the Nigerian economy and involves small scale farmers scattered over wide expanse of land with small holding ranging from 0.5-3.0 ha per farm land, characterized by rudimentary farm systems, low capitalization and low yield per hectare ${ }^{[1]}$. The roles of agriculture remain significant in the Nigerian economy despite the strategic importance of the oil sector. 
Groundnut (Arachis hypogea L.) is an annual, self-pollinated, growing plant found in many tropical, subtropical and temperate countries of the world ${ }^{[2]}$. It is now grown in about 108 countries of the world ${ }^{[3]}$. Asia with $63-66 \%$ land mass produces $71.72 \%$ of world groundnut followed by Africa with $18.6 \%$ production and North-Central America with 7.5\% ${ }^{[4]}$.

The major food crops of Adamawa State according to Adebayo and Tukur ${ }^{[5]}$ are mainly cereals, legumes and root crops while the cash crops are mainly cotton, groundnut and sugar cane. The variable climatic and edaphic factors of the state as well as cultural and socio-economic factors are adduced for the distribution of food and cash crops in the State. In the North-East Zone, groundnut is a major cash crop produced, especially in Hong ${ }^{[6]}$. Reported that seed yield in Northern Nigeria is about $3000 \mathrm{~kg} \mathrm{ha}^{-1}$. Adamawa Agricultural Development Programme, ADADP ${ }^{[7]}$ enumerated groundnut types commonly grown in Adamawa State to include; "Ordaaji” (2 nuts/shell), "Kwamakuni", (3 nuts/shell), "Kwathrumthrum" (2 nuts/shell larger) "Kwanyambi” or Ex Dakar and Kampala (brown/white striped nuts).

Stored food commodities are severely damaged by different groups of fungi including Aspergillus spp. Fusarium spp. and Penicillium spp. Aspergillus flavus is common in tropical and subtropical countries and cause contaminationas a result of moulding of badly stored commodities such as groundnut, cereal and cotton seeds ${ }^{[8]}$.

Fungi such as Aspergillus niger (brasiliensis) Aspergillus flavus, Alterneriadi anthocola, Curvularia lunata, Curvulari apellesecens, Fusarium oxysporum, Fusarium equiseti, Microphomina phaseolina, Rhizopus stolonifer, Penecillium digitatum and Penecillium chrysogenum cause discolouration, rotting, shrinking, seed necrosis, loss in germination capacity and toxification to oil seeds ${ }^{[9]}$. These fungi are associated with heavy loss of seeds, fruits, grains, vegetables and other plant products during picking, transit and storage rendering them unfit for human consumption even by producing mycotoxins and affecting their total nutritive value $^{[10,11]}$. The tropical climate with high temperature and high relative humidity along with unscientific storage condition adversely affect the storage of cereal grains and oil seed and this can lead to the total loss of seed quality $^{[12]}$.

Groundnut seed is susceptible to a wide range of pathogens and pests which cause a lot of damage to the crop, thereby reducing yield ${ }^{[13]}$.

Groundnut (Arachis hypogea L.) is an important oil seed crop in Nigeria and is widely grown in the tropics and sub-tropics ${ }^{[14]}$. It is one of the most important crops that have the ability to thrive on newly reclaimed sandy soils as a legume of high nutritive value as well as being a source of edible oil ${ }^{[15]}$. Moulds are associated with heavy loss of seeds, fruits, grains, vegetables and other plant products during picking, transit and storage rendering them unfit for human consumption even by producing mycotoxins and affecting their total nutritive value ${ }^{[10,11]}$ there is therefore, need to identify the pathogens prevalent in the area and assess their threat to this crop that is of utmost importance to the community (Kilba) and come up with an alternative control method other than the conventional un eco-friendly fungicides to control the fungi associated with the postharvest rot of groundnut. This research seeks to assess the incidence of postharvest rot of groundnuts as well as the fungal pathogens responsible in all the eight districts of Hong Local Government Area.

\section{MATERIALS AND METHODS}

Study area: A survey for the incidence and severity of groundnut rot in storage was carried out in Hong Local Government Area of Adamawa State (Fig. 1). The Local Government is divided into 7 districts which served as the locations for the survey. The districts are namely Hong, Pella, Gaya, Kulinyi, Dugwaba, Hildi and Uba (Fig. 2).

The isolation and identification of fungi associated with groundnut spoilage, determination of the pathogenicity of the isolates were conducted in the Medical Laboratory of Microbiology Department, Modibbo Adama University of Technology (MAUTECH) Yola from 18th July 2016-24th October 2016.

Hong Local Government Area is situated on Latitude $10.3^{\circ}$ and Longitude $12.40^{\circ}$ and $13^{\circ} \mathrm{E}$ it has a tropical climate marked by the dry and rainy seasons, the rainy season commences in April and ends in October, the average rainfall is $759 \mathrm{~mm}$, the wettest months are August and September, the dry season starts from November and ends in April, the temperature is moderately hot ranging from $25-35^{\circ} \mathrm{C}^{[5]}$.

Adamawa State is located at the North-Eastern part of Nigeria and lies between Latitudes $7^{\circ}$ and $11^{\circ} \mathrm{N}$ of the equator and between Longitudes $10^{\circ}$ and $14^{\circ} \mathrm{E}$ of the Greenwich Meridian. It shares boundaries with Taraba State in the South and West, Gombe in its North West, Borno to the North and Cameroon Republic along its Eastern borders. It lies in the Northern Guinea Savanna ecological zone ${ }^{[5]}$.

Source of samples: Samples of unshelled groundnut seeds of 2 genotypes namely Kampala and "Kwathrumthrum" were collected from 1 major market in each of the 7 districts namely Hildi, Kulinyi, Dugwaba, Uba, Gaya, Pella and Hong. 50 of the samples of each genotype were purchased from seller (2 randomly selected sellers/traders within the selected market) in each district making a total of 700 being collected from the various districts, the samples were conveyed to the laboratory in a dry clean polythene bag.Groundnut samples were labelled according to location and then photographed (Fig. 3 and 4a, b). 


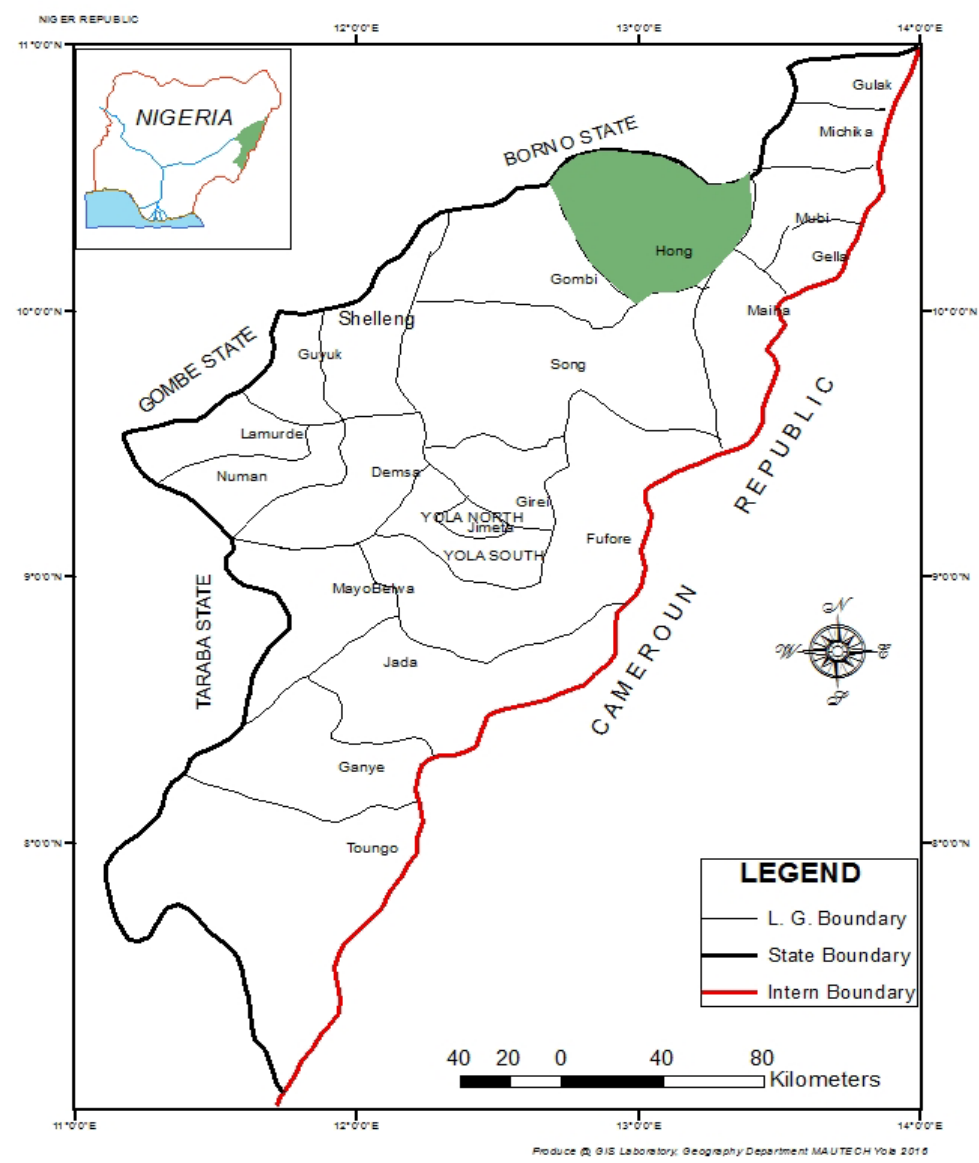

Fig. 1: Map of Adamawa State showing the study area

Incidence of rot on groundnut in storage: Incidence of rot of groundnut in storage was carried out. The samples purchased from the markets were assessed by determining the number of groundnut seeds showing rot out of the total number of groundnut seeds purchased from the market. The incidence of fungal spoilage/rot was expressed in percentage using the equation:

$$
\text { Incidence of fungal disease }=\frac{\begin{array}{c}
\text { Number of rotted groundnut } \\
\text { seeds collected }
\end{array}}{\begin{array}{c}
\text { Total number of the } \\
\text { groundnut seeds collected }
\end{array}} \times 100
$$

Sterilization of inoculation room and instruments: Sterilization of laboratory environment was carried out in order to avoid contamination of the bench and tables used for inoculation were swapped clean using 95\% ethanol and UV light switched on for $30 \mathrm{~min}$ before carrying out inoculation. Petri-dishes were sterilized at $160^{\circ} \mathrm{C}$ for $1 \mathrm{~h}$ in the oven, forceps, needles used for inoculation were sterilized by flaming and dipping into methylated spirit to cool.
Preparation of Potato Dextrose Agar (PDA): About $39 \mathrm{~g}$ of Potato Dextrose Agar (PDA) was dissolved in $1 \mathrm{~L}$ of distilled water, the Potato Dextrose Agar was then poured into two $500 \mathrm{~mL}$ conical flask then plugged with cotton wool and wrapped with aluminium foil before autoclaving it $121^{\circ} \mathrm{C}$ for $15 \mathrm{~min}$ at $10 \mathrm{lbs}$. pressure and $6 \mathrm{~mL}(0.1 \%)$ of streptomycin was added to the litre of sterilized media and swirled gently to mix properly, just before pouring into Petri dishes to prevent bacterial growth and allowed to cool and solidify according to the method of Suleiman and Michael ${ }^{[16]}$.

Isolation of pathogens: Under aseptic conditions the diseased sample of groundnut seeds showing rot was picked with a pair of sterile forceps. The seeds were then immersed into $1 \%$ sodium hypochlorite solution contained in a sterile $90 \mathrm{~mm}$ diameter petri-dish for surface sterilization for $30 \mathrm{sec}$, the sterilized seeds were then rinsed in three changes of sterile distilled water and then blotted dry between sterile filter papers. With a flamed and cooled pair of forceps, each sterilized seed was then 


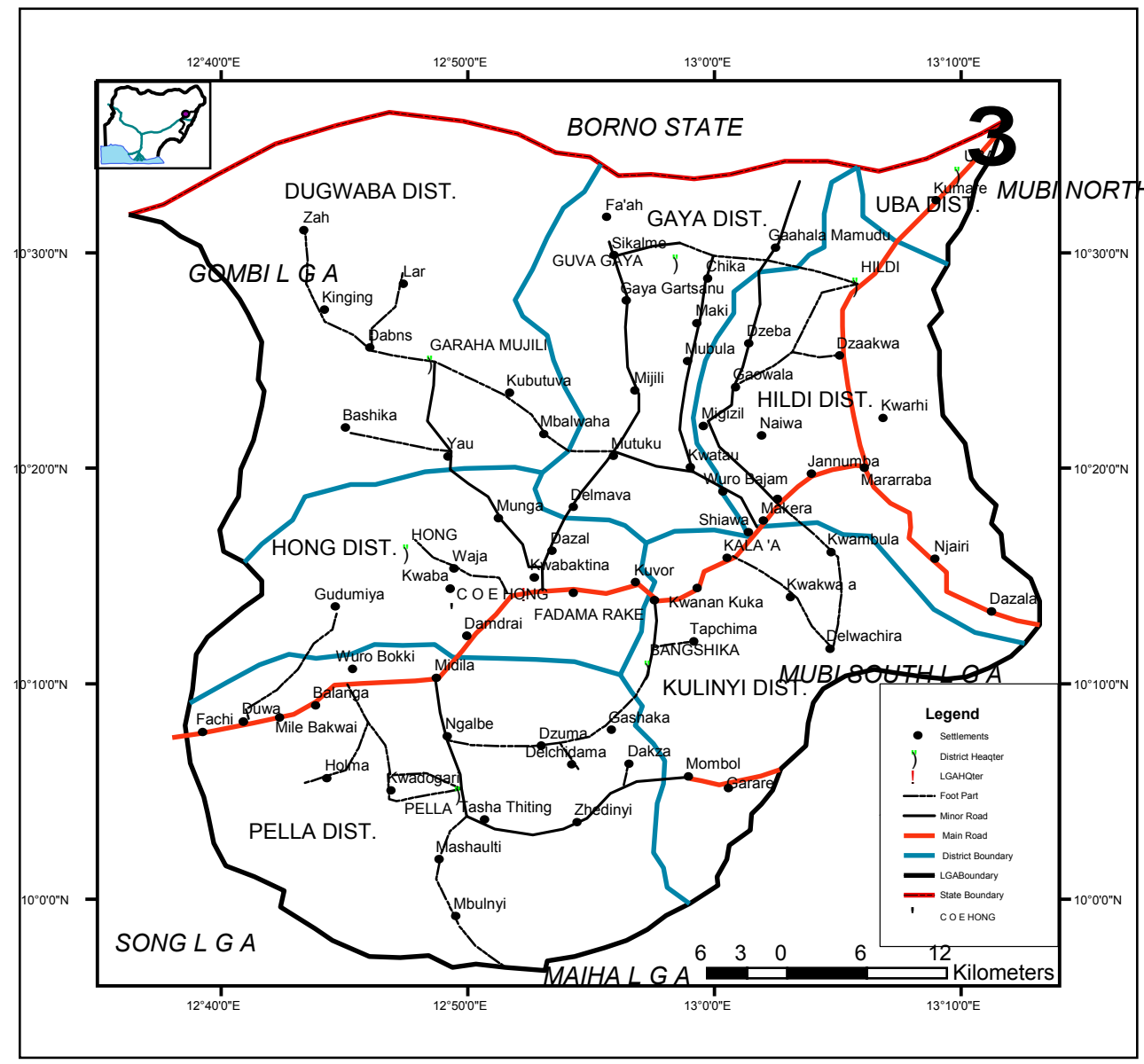

Fig. 2: Hong Local Government Area showing the study sites; GIS Laboratory Department of Geography, Mautech, Yola 2015

(a)

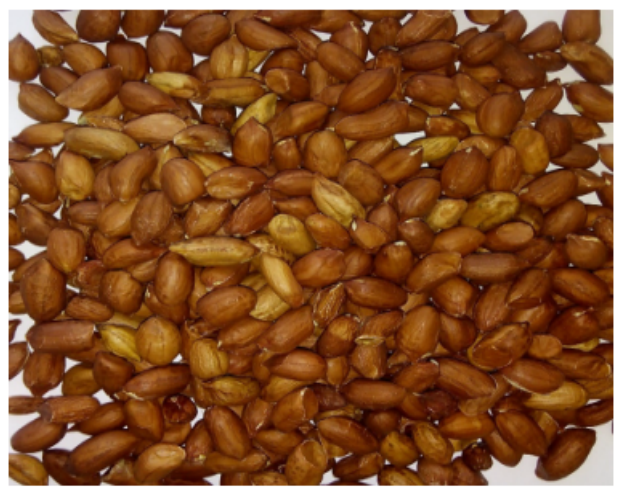

(b)

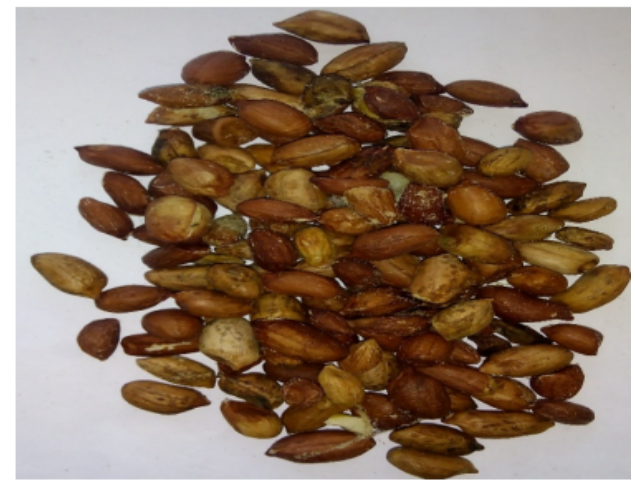

Fig. 3(a-b): a) Sample of healthy "Kwathrumthrum" groundnut seeds and b) Sample of "Kwathrumthrum" diseased groundnut seeds

split and plated aseptically on $90 \mathrm{~mm}$ diameter Petri-dish containing sterile solidified Potato Dextrose Agar (PDA) and incubated at an average room temperature of $33 \pm 20^{\circ} \mathrm{C}$ for 7 days (i.e., immediately when new colonies begin to grow) before sub-culturing on fresh sterilize PDA using the method of Klich and Pitt ${ }^{[17]}$ and Robert et al ${ }^{[18]}$ 
(a)

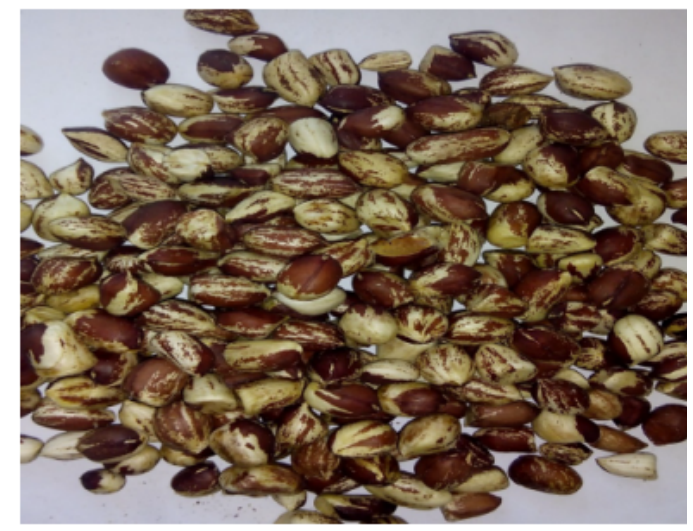

(b)

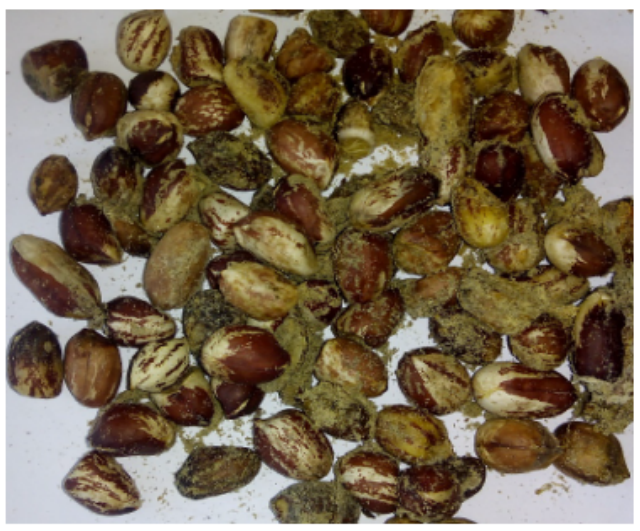

Fig. 4(a, b): a) Sample of healthy Kampala groundnut seeds and b) Sample of diseased Kampala groundnut seeds

Pure colonies were photographed, pure colonies were obtained from hyphal tip transfer to fresh PDA, pure isolates of fungal species obtained were stored on solidified sterile PDA in Mc-Cartney bottles and these were appropriately labelled according to organism. The slant was initially corked loosely to allow the content fungus to grow and then was tightly corked and stored in a freezer to serve as stock culture.

Identification of the isolated pathogens: Microscopic examination was carried out to observe the structure and characteristics of the fungal isolates. A sterile needle was used to pick a portion of the hyphae/spore and placed on a sterile glass slide stained with lacto-phenol blue and examined under the photographic microscope using the method of Fawole and Oss ${ }^{[19]}$. Micrograph of the isolates showing (conidia etc.) and the morphological and cultural characteristics observed were compared with structures in the identification guides of the center for research on pathogenic fungi and of Barnett and Hunter ${ }^{[20]}$.

Pathogenicity test: Pathogenicity test was carried out using techniques of Fajana ${ }^{[21]}$. Healthy dried groundnuts seeds were surface sterilized with $1 \%$ sodium hypochlorite (NHCL) solution for $30 \mathrm{sec}$ to remove surface contaminants and rinsed in 3 changes of sterile distilled water and then dried between a $12 \mathrm{~cm}$ diameter Whatman filter paper. The cultured isolates were dissolved into sterile distilled water and poured into $9 \mathrm{~cm}$ diameter petri dish laid with cotton wool and filter paper (Whatman No. 1). The 5 healthy seeds of $A$. hypogea were spread on each plate and incubated. The control set up seeds were treated with sterile distilled water and incubated the level of rot was measured ${ }^{[21]}$.

The set up was arranged in 3 replicates and incubated for 7 days. On establishment of rot, innoculum from the infected seed was re-isolated and compared with the first isolate. Result was analysed using Statistics for Agricultural Sciences (SAS). Isolate's virulence was assessed based on Da silva and Bettiol ${ }^{[22]}$ pathogenic potential of grouping isolates: 0-20 low virulent group, 21-40 moderately virulent group, 41-60 highly virulent group, 61-80 very highly virulent group, above 80 totally virulent group.

Effect of pathogen on germination of seeds: The effect of pathogen on germination of seeds was carried out using the techniques ${ }^{[21]}$. The 3 healthy seeds were placed on a plate and inoculated with each of the pathogen, the control seeds were with sterile distilled water. Germination was determined through the equation:

$$
\frac{\text { Number of seeds ger min ated }}{\text { Total number of seeds plated }} \times 100
$$

Effect of pathogen on growth of seedlings: Effect of the pathogen on the growth of the seedlings was carried out following the inoculation procedure. The 3 healthy seeds of $A$. hypogea inoculated with eachpathogen were spread on each plate and incubated in the dark. The control seeds were treated with sterile distilled water. The lengths $(\mathrm{mm})$ of the radicles and plumule emerging from the seeds were measured for 7 days using a measuring ruler. The set up was arranged in 3 replicates and kept for 7 days. Result was analysed using statistical analysis system.

\section{RESULTS AND DISCUSSION}

Incidence of groundnut rot in Hong Local Government Area: Results of the study showed that incidence of rot varied among all the 7 districts at $99.99 \%$ level of probability in the case of Kampala, the highest 
incidence of rot occurred in Hong $(8.67 \%)$ with the least in Dugwaba $(5.33 \%)$ district Table 1 . The percentage incidence on the "Kwathrumthrum" showed the highest incidence occurring in Hong $(6.67 \%)$ with the least in Uba $(2.67 \%)$ district Table 2.

Fungal isolates of groundnut in Hong Local Government Area: Fungi found associated with groundnut rot in the 7 districts of Hong Local Government Area were Aspergillus niger (A. brasiliensis), Aspergillus flavus, Penicillium chrysogenum, Rhizopus stolonifer, Pseudaiiescheria boydii, Paecilomyces lilacinus, Cylindrocarpon lichenicola and Scedosporium prolificans.

Frequency of fungal isolates (\%) on groundnut in Hong Local Government Area: Occurrence of the isolates on rotten groundnut seeds in Hong Local Government Area $(\mathrm{p}=0.05)$ showed a wide variation with in the 7 districts Table 3 . The highest occurrence of Aspergillus niger was in Kulinyi (15.17), Dugwaba (12.83) and Hildi (11.83\%) followed by Pella (11.17), Gaya (8.83) and Hong (8.50\%) and then by Uba (6.83\%). For Aspergillus flavus its highest occurrence was in Gaya (11.67\%) followed by Pella $(10.50 \%)$, Dugwaba (10.50\%), Uba (9.17\%), Kulinyi (6.83\%), Hildi (4.33\%), Hong $(2.83 \%)$. Penicillium chrysogenum occurrence was high at Hildi (5.67), Pella (5.50), Uba (5.00), Hong (4.33), Gaya (4.17), Kulinyi (2.67) and Dugwaba (1.17\%). The highest occurrence for Rhizopus stolonifer was at Hildi (5.00), Gaya (2.83), Uba (2.00), Dugwaba (1.17) and Hong $(1.33 \%)$ followed by Kulinyi $(0.00)$ and Pella $(0.00 \%)$. Pseudaiiescheria boydii ranked high in Dugwaba (2.83) and Hong (2.83\%) followed by Gaya (1.50), Hildi (1.33) and Uba (1.00\%) followed Kulinyi $(0.00)$ and Pella (0.00\%). For Paecilomyces lilacinas high occurrence was in Uba (7.00\%) followed by Dugwaba (2.83) then Pella (1.67) Gaya (1.50) and Hong (1.50\%)

Table 1: Groundnut variety used for the study

\begin{tabular}{lllll}
\hline Subspecies & Variety & $\begin{array}{l}\text { Botanical } \\
\text { types }\end{array}$ & Seed coat colour & $\begin{array}{c}\text { Pod size } \\
\mathrm{cm}\end{array}$ \\
\hline Fastigiata & Kampala & Valencia & Red-white (var) & $3-4$ \\
Hirsuta & Kwathrumthrum & Peruvian & Brown & $3-4$ \\
\hline
\end{tabular}

and then Hildi 0.00 and Kulinyi $0.00 \%$. There was a higher occurrence of Cylindrocarpon lichenicola was in Pella 3.83, Hong 1.33 and Hildi $1.33 \%$ followed by Uba 0.00 , Gaya 0.00, Dugwaba 0.00 and Kulinyi $0.00 \%$. Scedosporium prolificans recorded a higher occurrence in Hong 2.83 and Dugwaba 2.83 followed by Hildi 1.33 and Uba 1.33 then Kulinyi 0.00, Pella 0.00 and Gaya $0.00 \%$.

Virulence of rot of pathogens: The eight isolates were confirmed to be pathogenic as they produced rot lesions when inoculated to both the healthy genotypes of the groundnut seed. Virulence of the isolates also varied. Aspergillus flavus was rated as totally virulent, Aspergillus niger (brasiliensis) as very highly virulent, Penicillium chrysogenum and Rhizopus stolonifer as highly virulent, Pseudaiiescheria boydii as moderate virulent group, Paecilomyces lilacinus, Cylindrocarpon lichenicola and Scedosporium prolificans were the low virulent group Table 4 (Fig. 5-12).

Effect of pathogens on groundnut seed germination: There was a significant reduction in the rate of germination of seeds inoculated with all the pathogens except for Pseudallescheria boydii and Cylindrocarpon lichenicola as compared to the control, the highest reduction in germination was by Rhizopus stolonifer and Scedosporium prolificans (11.00\% in the Kampala). The highest reduction in the "Kwathrumthrum" cultivar was by the Aspergillus flavus $11.00 \%$ ). However, there was no significant variation for reduction in germination between the Kampala and "Kwathrumthrum" (Table 5).

Table 2: Incidence (\%) of groundnut rot in Hong Local Government Area of Adamawa State, Nigeria

\begin{tabular}{lcc}
\hline Districts & Kampala & Local \\
\hline Kulinyi & 7.33 & 6.00 \\
Hong & 8.67 & 6.67 \\
Pella & 6.67 & 5.33 \\
Dugwaba & 5.33 & 4.67 \\
Gaya & 7.33 & 4.00 \\
Hildi & 8.00 & 6.67 \\
Uba & 6.00 & 2.67 \\
LSD (0.05) & 1.68 & 1.31 \\
\hline LSD: Least Significant Difference &
\end{tabular}

Table 3: Frequency of occurrence (\%) of fungi isolated from groundnut seeds in Hong Local Government Area of Adamawa State, Nigeria

\begin{tabular}{|c|c|c|c|c|c|c|c|c|}
\hline \multirow[b]{2}{*}{ Location } & \multicolumn{8}{|l|}{ Pathogens } \\
\hline & $\begin{array}{l}\text { Aspergillus } \\
\text { brasiliensis }\end{array}$ & $\begin{array}{l}\text { Aspergillus } \\
\text { flavus }\end{array}$ & $\begin{array}{l}\text { Penicillium } \\
\text { chrysogenum }\end{array}$ & $\begin{array}{l}\text { Rhizopus } \\
\text { stolonifer }\end{array}$ & $\begin{array}{c}\text { Pseudaiiescheria } \\
\text { boydii }\end{array}$ & $\begin{array}{l}\text { Paecilomyces } \\
\text { lilacinus }\end{array}$ & $\begin{array}{c}\text { Cylindrocarpon } \\
\text { lichenicola }\end{array}$ & $\begin{array}{c}\text { Scedosporium } \\
\text { prolificans }\end{array}$ \\
\hline Kulinyi & 15.17 & 6.83 & 2.67 & 0.00 & 0.00 & 0.00 & 0.00 & 0.00 \\
\hline Hong & 8.50 & 2.83 & 4.33 & 1.33 & 2.83 & 1.50 & 1.33 & 2.83 \\
\hline Pella & 11.17 & 10.50 & 5.50 & 0.00 & 0.00 & 1.67 & 3.83 & 0.00 \\
\hline Dugwaba & 12.83 & 10.50 & 1.17 & 1.17 & 2.83 & 2.83 & 0.00 & 2.83 \\
\hline Gaya & 8.83 & 11.67 & 4.17 & 2.83 & 1.50 & 1.50 & 0.00 & 0.00 \\
\hline Hildi & 11.83 & 4.33 & 5.67 & 5.00 & 1.33 & 0.00 & 1.33 & 1.33 \\
\hline Uba & 6.83 & 9.17 & 5.00 & 2.00 & 1.00 & 7.00 & 0.00 & 1.00 \\
\hline $\operatorname{LSD}(0.05)$ & 3.42 & 2.31 & 0.93 & 0.64 & 0.26 & 0.19 & 0.30 & 0.35 \\
\hline
\end{tabular}


Table 4: Virulence of fungal pathogens on groundnut seeds (\%)

\begin{tabular}{lll}
\hline & Pathogenic potential & \\
& --------------------------- \\
Pathogen & Kwathrumthrum & Kampala \\
\hline Aspergillus flavus & Totally virulent & Totally virulent \\
Aspergillus brasilensis & Very highly virulent & Very highly virulent \\
Penicillium chrysogenum & Highly virulent & Very highly virulent \\
Rhizopus stolonifer & Highly virulent & Very highly virulent \\
Pseudaiiescheria boydii & Moderately virulent & Moderately virulent \\
Paecilomyces lilacinus & Low virulent & Low virulent \\
Cylindrocarpon lichenicola & Low virulent & Low virulent \\
Scedosporium prolificans & Low virulent & Low virulent \\
\hline D-20\% Low
\end{tabular}

0-20\%-Low Virulent Group, 2-40\%-Moderately Virulent Group, 41-60\%-High Virulent Group, 61-80\%-Very High Virulent Group, $80 \%$ and Above-Totally Virulent Group

Table 5: Effect of pathogen on groundnut seed germination (\%) in Hong Local Government Area of Adamawa State, Nigeria

\begin{tabular}{lcc}
\hline Organism & Kampala & Kwathrumthrum \\
\hline Aspergillus niger & 22.33 & 22.33 \\
Aspergillus flavus & 22.33 & 11.00 \\
Penicillium chrysogenum & 22.33 & 22.33 \\
Rhizopus stolonifer & 11.00 & 22.33 \\
Pseudaiiescheria boydii & 33.33 & 22.33 \\
Paecilomyces lilacinus & 22.33 & 22.33 \\
Cylindrocarpon lichenicola & 0.00 & 33.33 \\
Scedosporium prolificans & 11.00 & 22.33 \\
Control & 33.33 & 33.33 \\
LSD $(0.05)$ & 0.81 & 0.93 \\
\hline
\end{tabular}

LSD; Least Significant Difference

Table 6: Effect of pathogens on growth of seedlings of "Kwathrumthrum" groundnut (mm) in Hong Local Government Area of Adamawa State, Nigeria

\begin{tabular}{lcc}
\hline Pathogen & Radicle & Plumule \\
\hline Aspergillus niger & 20.00 & 16.67 \\
Aspergillus flavus & 7.33 & 3.33 \\
Penicillium chrysogenum & 21.67 & 10.33 \\
Rhizopus stolonifer & 19.67 & 10.67 \\
Pseudaiiescheria boydii & 26.00 & 24.33 \\
Paecilomyces lilacinus & 12.67 & 22.67 \\
Cylindrocarpon lichenicola & 24.33 & 14.00 \\
Scedosporium prolificans & 13.33 & 9.67 \\
Control & 39.33 & 33.67 \\
LSD (0.05) & 22.70 & 16.00 \\
\hline
\end{tabular}

LSD; Least Significant Difference

Effect of pathogens on growth of seedlings: There was no significant reduction in the growth of seedlings (plumule and radicle) for the Kampala, however, for the "Kwathrumthrum" growth of radicle was significantly reduced for all pathogen-inoculated seeds except Pseudallescheria boydii and Cylindrocarpon lichenicola for the plumule all seedings showed a significant reduction in growth except Pseudallescheria boydii and Paecillomyces lilacinus (Table 6).

Incidence of the groundnut rot was universally spread in all the seven districts of Hong Local Government Area of Adamawa State, there are reports according to Natarajan ${ }^{[23]}$ who reported that the method of storage

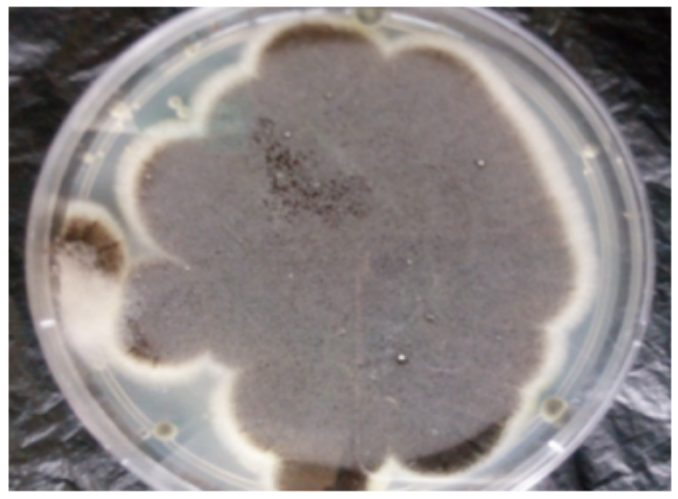

Fig. 5: 7 days old culture of Aspergillus niger syn Aspergillus brasiliensis

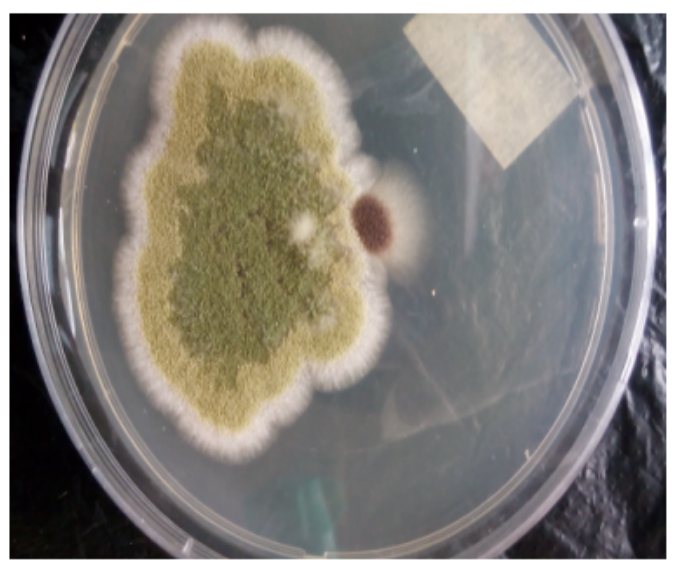

Fig. 6: 7 days old culture of Aspergillus flavus

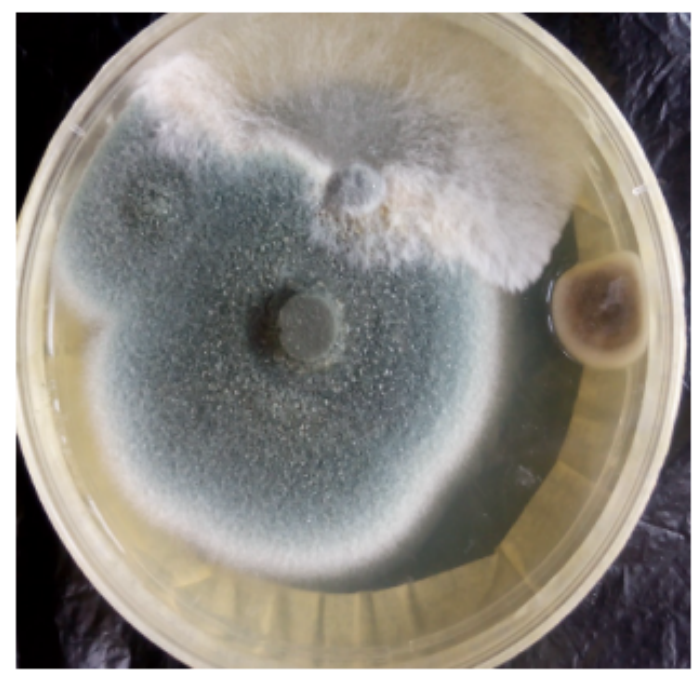

Fig. 7: 7 days old culture of Penicillium chrysogenum 


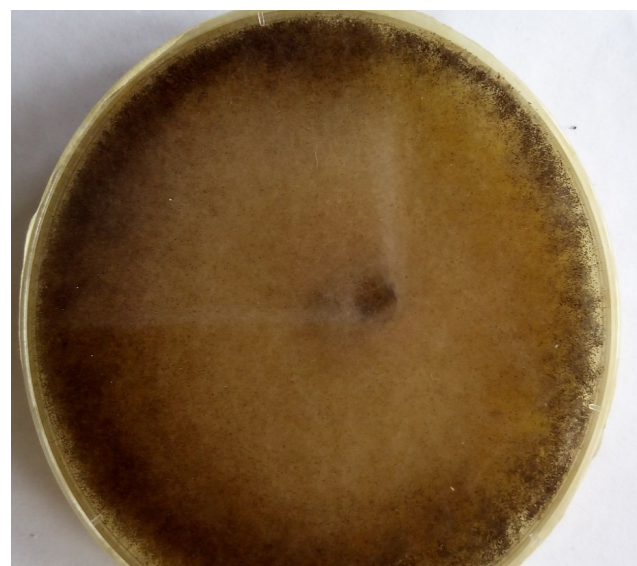

Fig. 8: 7 days old culture of Rhizopus stolonifer

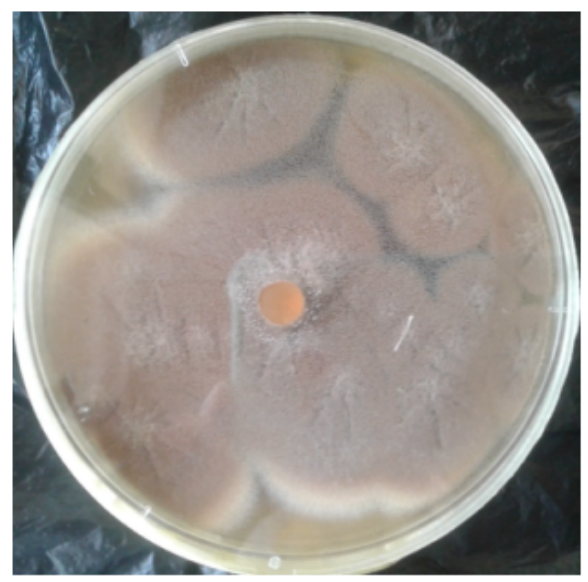

Fig. 9: 7 days old culture of Pseudaiiesceria boydii

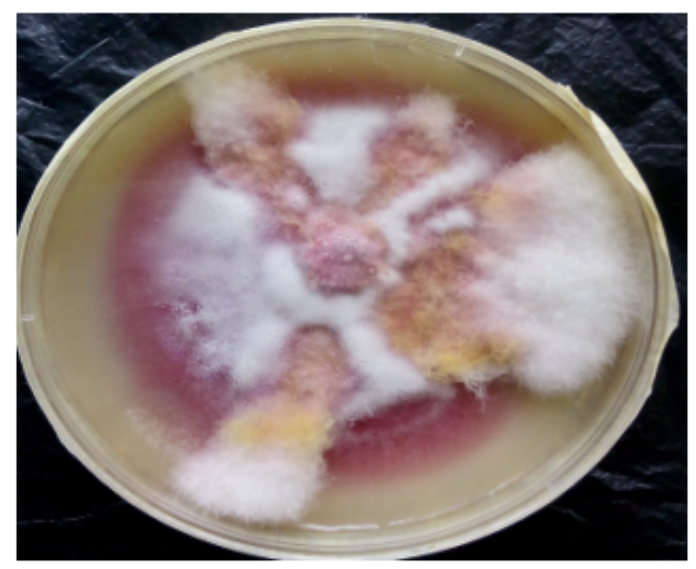

Fig. 10: 7 days old culture of Cylindrocarpon lichenicola

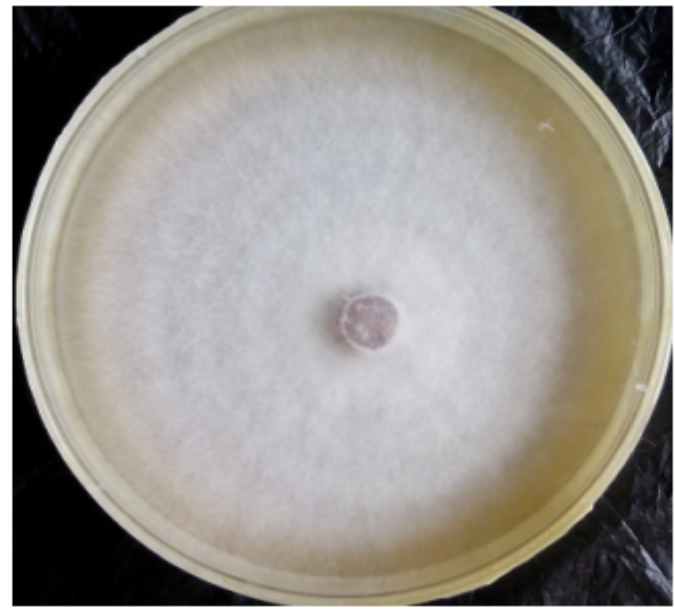

Fig. 11: 7 days old culture of Paecilomyces lilacinus

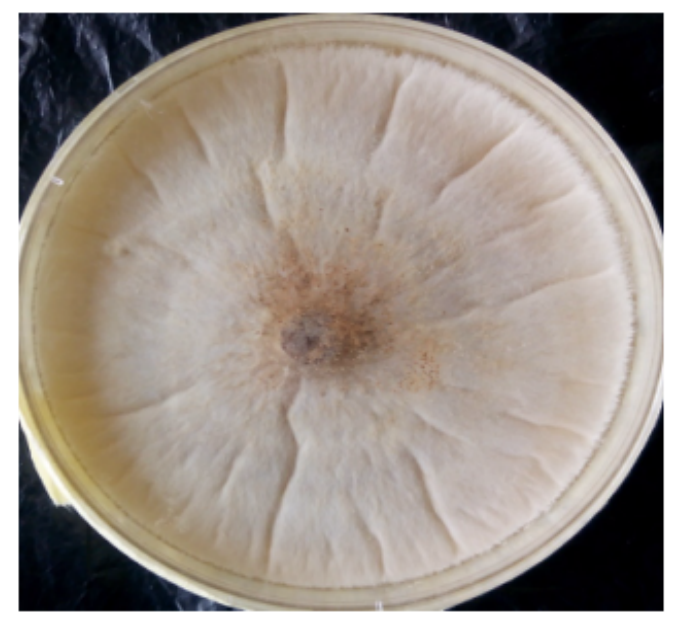

Fig. 12: 7 days old culture of Scedosporium prolificans

of the seeds and the initial seed quality affect the deterioration of the seed and would be subjected to invasion by fungi. Nakail et al. ${ }^{[2]}$ recorded the susceptibility of groundnut to colonization of Aspergillus flavus especially during storage.

The 8 fungal pathogens were found on the groundnuts in Hong Local Government Area of Adamawa State, the presence of these pathogens agrees with the report of Sullivan who reported that Aspergillus flavus, Rhizopus stolonifer and Penicillium spp. are storage pathogens of groundnut seeds which are highly susceptible to a number of disease causing pathogens because the seeds are very rich in nutrients for the fungi to thrive. Vikas and Mishra ${ }^{[25]}$ isolated 9 species of fungi which include Aspergillus flavusPenicillium spp. Fusarium spp., Aspergillus niger from the seeds of different varieties of groundnut during storage of 1 year. 
According to Chavan and Kakde ${ }^{[9]}$ the most occurring moulds of post-harvest products in storage were commonly the Penicillium, Aspergillus, Rhizopus and Fusarium and this agrees with the findings of the research as the most occurring pathogens in all the seven districts are Aspergillus flavus and Aspergillus niger (brasilenesis). Chavan ${ }^{[26]}$ found that the species of Aspergillus, Penicilium, Fusarium, Rhizopus and Alternaria were commonly occurring post-harvest moulds in storage conditions.

Aspergillus flavus as recorded from the research was totally virulent and as found in other reports that most of the species of Aspergillus were dominant and play a vital role in the seed bio-deterioration, Ibiam and $\mathrm{Egwu}^{[27]}$ reported that among different species of fungal infection, Aspergillus flavus was the most predominant one.

Most pathogens caused a significant reduction in seed germination rate and growth of seedlings in both the Kampala and " Kwathrumthrum". This agrees with reports by Chavan and Kakde ${ }^{[9]}$ fungi such as Aspergillus niger (brasiliensis) Aspergillus flavus, Alterneria anthocola, Curvularia lunata, Curvulari apellesecens, Fusarium oxysporum, Fusarium equiseti, Macrophomina phaseolina, Rhizopus stolonifer, Penecillium digitatum and Penecillium chrysogenum cause shrinking, seed necrosis, loss in germination capacity and toxification of oil seeds. Soil-borne fungal pathogens are a major constraint in crop production by infecting roots ${ }^{[28,29]}$.

\section{CONCLUSION}

The frequent occurring fungi were Aspergillus niger (brasilensis) and Aspergillus flavus while the most virulent was Aspergillus flavus. There was significant reduction in seed germination and seedling growth at $99.99 \%$ probability level for both the Valencia (Kampala) and Peruvian (Kwathrumthrum) from 33.33\% for un-inoculated to $11.00 \%$ for inoculated. Proper storage practices to reduce groundnut rot as well as enhance seed viability are therefore, suggested.

\section{REFERENCES}

01. Kolawole, O. and S.O. Ojo, 2007. Economic efficiency of small scale food crop production in Nigeria: A stochastic frontier approach. J. Soc. Sci., 14: 123-130.

02. Halima, A.S., 2000. Isolation and preliminary identification of fungi in stored groundnut. Higher National Diploma Project, Department of Science Laboratory Technology, Kano State Polytechnic, Kano, Nigeria, Nigeria.
03. Srivastava, A.K., T. Gaiser and F. Ewert, 2016. Climate change impact and potential adaptation strategies under alternate climate scenarios for yam production in the sub-humid Savannah Zone of West Africa. Mitigation Adapt. Strategies Global Change, 21: 955-968.

04. Ajeigbe, H.A., F. Waliyar, C.A. Echekwu, A. Kunihya and B.N. Motagi et al., 2015. A Farmers Guide to Profitable Groundnut Production in Nigeria. ICRISAT, Patancheru, Hyderabad, Telangana, India,.

05. Adebayo, A.A. and A.E. Tukur, 1999. Adamawa State in Map (Editor). 1st Edn., Federal University of Technology Yola, Yola, Nigeria,.

06. Adebayo, A.A., 1997. The agroclimatology of rice production in Adamawa State. Ph.D Thesis, Federal University of Technology Yola, Yola, Nigeria.

07. ADADP, 1996. Crop Recommendation for extension workers in Adamawa State. ADP, LLC, Roseland, New Jersey, USA.

08. Weiss, T.J., 1983. Physical and Chemical Properties of Fats and Oils and Their Uses. 2nd Edn., AVI Publishers, Westport, USA., pp: 25-31, 44-84.

09. Chavan, A.M. and R.B. Kakde, 2008. Studies on abnormal oilseeds mycoflora from Marathwada region. Bionano Frontier, 2: 101-104.

10. Verma, S.S., R.P.S. Tomer and U. Verma, 2003a. Loss of viability and vigour in Indian mustard seeds stored under ambient conditions. Seed Res., 31: 98-101.

11. Verma, S.S., U. Verma and R.P.S. Tomer, 2003b. Studies on seed quality parameters in deteriorating seeds in Brassica (Brassica campestris). Seed Sci. Technol., 31: 389-396.

12. Bhattacharya, K. and S. Raha, 2002. Deteriorative changes of maize, groundnut and soybean seeds by fungi storage. Mycopathologia, 155: 135-141.

13. Weiss, E., 2000. Oilseed Crops. 2nd Edn., John Wiley and Sons, Hoboken, New Jersey, USA., ISBN:9780632052592, Pages: 384.

14. Nigam, S.N., R.N. Rao, J.C. Wynne, J.H. Williams and M. Fitzner et al., 1994. Effect and interaction of temperature and photoperiod on growth and partitioning in three groundnut (Arachis hypogaea L.) genotypes1. Ann. Appl. Bio., 125: 541-552.

15. Spears, J.F., D.L. Jordan and J.E. Bailey, 2002. Peanut seed production: A guide for producers of Virginia-type peanut seed. NC. Coop. Ext. Serv. Bull., 662: 1-17. 
16. Suleiman, M.N. and A.J. Michael, 2013. Bioactive properties of Azadirachta Indica and Cymbopogan citrates on some pathogens of guinea corn seeds in storage. Niger. J. Mycol., 5: 74-81.

17. Klich, M.A. and J.I. Pitt, 1988. A Laboratory Guide to Common Aspergillus Species and their Teleomorphs. Commonwealth Scientific and Industrial Research Organisation, Division of Food Processing, North Ryde, Australia.

18. Robert, A.S., E.S. Hoekstra, J.C. Frisvad and O. Filtenborg, 1996. Introduction to Food-borne Fungi. Centraalbureau Voor Schimmelcultures, Netherlands,.

19. Fawole, M.O. and B.A. Oso, 1995. Laboratory Manual of Microbiology. Spectrum Books Limited, Nigeria, pages: 127.

20. Barnett, H.L. and B.B. Hunter, 1998. Illustrated Genera of Imperfect Fungi. 4th Edn., APS Press, St. Paul. Minnesota.

21. Fajana, A., 2013. Cytotoxic and growth inhibitory effects of the methanol extract of tridax procumbens linn (Asteraceae). J. Pharmacogn. Phytochem., 2: 26-32.

22. Da Silva, J.C. and W. Bettiol, 2005. Potential of non-pathogenic Fusarium oxysporum isolates for control of Fusarium wilt of tomato. Fitopatol. Brasil., 30: 409-412.
23. Natarajan, S., 1996. Influence of season and provenance on quality of groundnut seed. M.Sc. (Ag.) Thesis, Tamil Nadu Agriculture University, Coimbatore, (India).

24. Nakail, V.K. L. de Oliveira Rocha, E. Goncalez, H. Fonseca, E.M.M. Ortega and B. Corre, 2008. Distribution of fungi and aflatoxins in a stored peanut variety. Food Chem., 106: 285-290.

25. Vikas, P.V. and U.S. Mishra, 2010. Effect of temperature on dynamics of storage fungi of oil seeds. Int. J. Plant Res., 23: 9-14.

26. Chavan, A.M., 2011. Nutritional changes in oilseeds due to Aspergillus spp. J. Exp. Sci., 2: 29-31.

27. Ibiam, O.F.A. and B.N. Egwu, 2011. Post-harvest seed-borne diseases associated with the seeds of three varieties of groundnuts, (Arachis hypogaea L) Nwakara, Kaki and Campalla. Agric. Biol. J. N. Am., 2: 598-602.

28. Abdel-Kader, M.M., N.S. El-Mougy and A.M.A. Ashour, 2002. Suppression of root rot incidence in faba bean fields by using certain isolates of Trichoderma. Egypt. J. Phytopathol, 30: 15-25.

29. Infantino, A., M. Kharrat, L. Riccioni, C.J. Coyne and K.E. McPhee et al., 2006. Screening techniques and sources of resistance to root diseases in cool season food legumes. Euphytica, 147: 201-221. 